Ramos "La banda sonora de la rutina II: música electrónica". A las 11:45 hrs. Rodrigo Castellanos presentó "Electrónica en vivo en la música contemporánea: pensamiento creativo e identidad".

El jueves 25 iniciaron las actividades a las 9:30 hrs con la charla de Juan Manuel Quinteros "Sincretismo y Pensamiento Instrumental", basado en el ciclo de piezas solistas Manifiesto. Luego a las 11:00 hrs. siguió la charla de Felipe Pinto d'Aguiar "Emergencias Musicales", y finalmente a las 12:30 hrs. Sebastián Vergara presentó "Máquinas: Tecnología y proceso creativo".

El viernes 26, último día de este encuentro, a las 9:30 hrs. se realizó la charla "Prosodia: Fonología, Métrica, Música” de Jaime Ramos. Luego a las 11:00 hrs., Álvaro Menanteau expuso el tema "Presencia española y latina en los orígenes del jazz: el ritmo de habanera". Finalmente se realizó una mesa redonda titulada "Pensamiento creativo e identidades del sur”, en la que participaron Felipe Pinto d'Aguiar, Juan Manuel Quinteros, Jaime Ramos, Rodrigo Castellanos y Sebastián Vergara. Su moderador fue Álvaro Menanteau.

A las 19:30 hrs. se llevó a cabo el concierto de clausura del encuentro en la Sala Aula Magna de la UACh. El director del Conservatorio, prof. Carrasco, y el coordinador del encuentro dirigieron emotivas palabras de agradecimientos y de despedida, especialmente a los invitados. El acto contó con la participación del Cuarteto de Alumnos del Conservatorio de Música UACh, y de la Orquesta de Alumnos del Conservatorio de Música UACh, bajo la dirección de Guillermo Rifo.

\title{
Primer Encuentro de Trabajadores de la Música
}

\author{
por \\ Vladimir Barraza Jeraldo \\ Conservatorio de Música \\ Universidad Austral de Chile, Chile \\ vbarraza@uach.cl
}

El 1 de noviembre de 2018, entre las 9:30 y las 18:30 hrs. se desarrolló el Primer Encuentro de Trabajadores de la Música, organizado por la Radio de la Universidad Austral de Chile (90.1 F.M.) y el sello discográfico Misisipi, representado por Javier Aravena. Se realizó en la sala Sergio Pineda del Conservatorio de Música de la Universidad Austral de Chile.

El encuentro se inició con palabras del director del conservatorio, Sr. Wladimir Carrasco, el director de la radio UACh, Sr. Miguel Millar, y el director del sello discográfico Misisipi, Sr. Javier Aravena.

Esta iniciativa tuvo entre sus principales objetivos reunir a representantes de músicos populares, clásicos y mapuches, especialmente de la Región de Los Ríos, para abordar en conjunto temas relacionados con la labor que desarrollan especialmente los músicos populares y que se conectan directamente con sus condiciones laborales, seguridad social, redes de fortalecimiento y posible formación de agrupaciones.

Se llevó a cabo una exposición titulada "La economía alrededor de los músicos", dictada por Helen Urra, periodista, encargada de la unidad de Fomento de las Artes e Industrias Creativas del Consejo Nacional de la Cultura y las Artes (CNCA), y por Marcelo Vera, ingeniero agrónomo y experto en negocios, además de exdirector de ProChile, institución encargada de promover las exportaciones de productos y servicios del país. 
Hubo posteriormente distintas ponencias, entre ellas, "Los derechos asociados al ejercicio de la música como profesión" dictada por Rafael Aguirre, músico y abogado; "Experiencia de producción colaborativa" presentada por Javier Aravena, músico; "Formación de asociaciones, agrupaciones y sindicatos", expuesta por Rudy Matus, músico; "Creación y patrimonio sonoro y poético de la música del sur”, a cargo de Alonso Núñez, musicólogo; "Historia social de la música en Valdivia", por Vladimir Barraza, y "La historia social de la música popular chilena” por Juan Pablo González, musicólogo. Al final de la jornada se conformaron mesas de trabajo, y se realizaron resúmenes de los planteamientos expuestos. El trabajo se desarrolló en tres grupos de diez personas como mínimo, y se enfatizó en las exposiciones realizadas durante el día.

Entre los logros de este primer encuentro se cuenta el afianzamiento de lazos entre la academia y la música popular, además de haber planteado desafíos conjuntos en torno a líneas de trabajo que recogieron las distintas expresiones de la música sureña.

Quedaron tareas pendientes, como la búsqueda de soluciones a la situación en que se encuentran los músicos populares, al no poder formar sindicatos integrados por trabajadores de la música, ya que no pertenecen a empresas públicas o privadas, y prima el ejercicio liberal de la profesión u oficio de músico. De todas maneras quedó como tarea investigar algunas alternativas, como por ejemplo, un organismo democrático constituido por personas que se asocian, en régimen de libre adhesión y baja voluntaria, para la realización de actividades sociales y económicas. En un próximo encuentro, que se estima realizar en marzo de 2019, se ha propuesto avanzar en una solución, que podría cristalizarse en una institución que agrupe a los músicos especialmente populares del sur de Chile.

Al término de la jornada se realizó un encuentro musical en el local "Perro Negro", a partir de las 21 horas con las presentaciones de Del Monte al Mar, La Rata Bluesera y Colelo, entre otros músicos. 